\title{
Edukacyjny wymiar cierpienia w biografii
}

\begin{abstract}
Streszczenie: Współczesne andragogiczne teorie uczenia się człowieka dorosłego zakładają, że doświadczenia życiowe inicjują aktywność edukacyjną. Uczenie się w okresie dorosłości nie wiąże się jedynie $\mathrm{z}$ zaplanowanym i sformalizowanym procesem kształcenia, ale również zachodzi w codzienności. W oparciu o koncepcję trajektorii Gerharda Riemanna i Fritza Schützego ukazano edukacyjny potencjał cierpienia wpisanego w biografię człowieka dorosłego. Egzemplifikacją tego są biografie tych osób, które pomimo bądź nawet pod wpływem cierpienia podjęły aktywność przyczyniającą się do ich rozwoju. Nie można jednak oczekiwać od każdego człowieka cierpiącego podjęcia takiej aktywności. Dostrzeżenie i wykorzystanie edukacyjnego i rozwojowego potencjału cierpienia uzależnione jest od wielu czynników, związanych zarówno z samą sytuacją cierpienia, jak i doświadczającym podmiotem.
\end{abstract}

Slowa kluczowe: cierpienie, biografia, trajektoria, edukacja, uczenie się.

\section{Educational dimension of suffering in biography}

Summary: Contemporary theories of adults learning assume that life experiences initiate educational activity. Therefore, learning in adulthood is not just the planned and formalized process, but also occurs in everyday life. Based on the concept of trajectory created by Gerhard Riemann and Fritz Schütze, the author presents educational potential of the suffering inherent in adult's biography. Exemplification of this are the biographies of those people who despite or even under the influence of the suffering undertook creative activity. But we cannot expect that every person suffering undertake such activity. The perception and use of educational and developmental potential of suffering is dependent on many factors, related both to the situation of suffering and experiencing entity.

Keywords: suffering, biography, trajectory, education, learning.

* Politechnika Wrocławska, Studium Nauk Humanistycznych i Społecznych, 50-377 Wrocław, pl. Grunwaldzki 11; emilia.mazurek@pwr.wroc.pl 
Współczesny człowiek ukierunkowany jest przede wszystkim na przeżywanie doznań związanych z przyjemnością. Tymczasem ludzkiej egzystencji towarzyszy cierpienie, a zadaniem człowieka dorosłego staje się radzenie sobie z jego wpływem, czy - jak ująłby to Viktor E. Frankl $(1998,2009)$ - nadawanie mu znaczenia i poszukiwanie w nim sensu życia. „Cierpienie jest złożonym doświadczeniem poznawczo-emocjonalnym obejmującym stany fizjologiczne, psychiczne i duchowe" (Okła, 2009, s. 14). W literaturze przedmiotu odnaleźć można różnorodne stanowiska autorów względem cierpienia (zob. Suchocka, 2007). Ujmowane jest ono jako „sytuacja graniczna” (Jaspers, 1978), wartość, sposób odnajdywania sensu życia (Frankl, 1998; Frankl, 2009), „doświadczenie egzystencjalnie znaczące" (Popielski, 2008), nieodłączny element życia człowieka, atrybut natury ludzkiej (Jan Paweł II, 2002), okoliczność sprzyjająca transgresji (Kozielecki, 2002), doświadczenie o potencjale edukacyjnym (Mazurek, 2013). Choć każdy z wymienionych autorów przedstawia swój sposób rozumienia istoty i sensu cierpienia, to jednak w każdym ujęciu można odnaleźć akcentowanie rozwojowego potencjału cierpienia. Aczkolwiek jego dostrzeżenie i wykorzystanie zależeć będzie przede wszystkim od samego doświadczającego podmiotu, jego postawy, osobowości, przebiegu dotychczasowej biografii, systemu wartości. Nie bez znaczenia w tej kwestii będzie jednak również sama sytuacja wyzwalająca cierpienie oraz otoczenie człowieka cierpiącego.

Czym zatem jest cierpienie? Jakie są jego źródła? Cierpienie nie jest tożsame $\mathrm{z}$ bólem fizycznym, ponieważ jest ono doświadczeniem wielowymiarowym, ingerują̨cym w różnorodne wymiary ludzkiej egzystencji. W zależności od źródła Lilia Suchocka (2007) wymienia następujące rodzaje cierpienia: fizyczne (spowodowane uszkodzeniem, okaleczeniem ciała lub chorobą), psychiczne (związane $\mathrm{z}$ trudną sytuacją egzystencjalną, zaburzającą prawidłowe funkcjonowanie psychiki), moralne (wynikające z utraty bądź braku możliwości osiągnięcia ważnej dla człowieka wartości), społeczne (powstające jako efekt nieprawidłowych, zaburzonych relacji człowieka z innymi ludźmi), egzystencjalne (utożsamiane $\mathrm{z}$ brakiem sensu życia), transcendentne (związane z ograniczonym sprawstwem człowieka, brakiem możliwości przekroczenia pewnych granic ludzkiego potencjału). Każdy z rodzajów cierpienia można wiązać z doświadczeniem straty, które choć wywołuje negatywne emocje, to może inspirować do refleksji i uczenia się.

\section{Doświadczenie straty jako źródło cierpienia}

Ludzie dorośli, wspominając swoje lata dzieciństwa bądź okres adolescencji, przywołują wydarzenia, które w sposób szczególny zapisały się w ich pamięci. Są wśród nich wydarzenia trudne, które wymagały ustosunkowania się do nich, nadania im znaczenia, a nierzadko również podjęcia jakiegoś działania. Sytuacje te poddawane są przez doświadczającego człowieka subiektywnej oce- 
nie poznawczej (zagrożenie versus wyzwanie) oraz ocenie własnego potencjału w poradzeniu sobie z problemem (poczucie bezradności versus poczucie sprawstwa, bierność versus aktywność, wycofanie versus poszukiwanie) (Okła, 2009). Wydarzenia te wyróżniają się spośród innych i bardzo często dotyczą utraty osoby znaczącej bądź utraty jakiegoś dobra, które nawet z perspektywy lat stanowi wartość. Czasem coś, co zostało utracone w przeszłości, sentymentalnie urasta do rangi czegoś bezcennego i w przekonaniu osoby, która doświadczyła straty, jest postrzegane jako coś bardziej wartościowego niż faktycznie dawniej takim było. Przykładem mogą być wspomnienia ludzi starszych reprezentujących pokolenie wojenne, którym wojna odebrała między innymi szczęśliwe, beztroskie dzieciństwo oraz szansę systematycznej edukacji. Niektórzy z nich kompensują sobie doświadczenie straty poprzez uczestnictwo w zajęciach proponowanych przez Uniwersytety Trzeciego Wieku lub podejmowanie innych form aktywności edukacyjnej. Innym przykładem może być młody człowiek, który nie dostał się na wymarzony kierunek studiów i w związku z tym podjął kształcenie na innym fakultecie. Pomimo ukończenia edukacji akademickiej i satysfakcji z wykonywanego zawodu może mieć poczucie, że utracił możliwość realizowania swej pasji.

Przykładów doświadczeń o charakterze straty można podać wiele. Występują one na każdym etapie rozwoju człowieka. Niektóre z nich wynikają z zadań rozwojowych (np. kryzys pustego gniazda, przejście na emeryturę, utrata sił witalnych w okresie późnej dorosłości). Inne z kolei związane są z trudnymi wydarzeniami życiowymi, które mogą zachodzić intencjonalnie (np. rozwód będący efektem wspólnej decyzji małżonków), ale również mogą występować wbrew woli człowieka (np. utrata zdrowia spowodowana przewlekłą chorobą somatyczną, śmierć członka rodziny, nabycie niepełnosprawności). Człowiek dorosły, analizując i interpretując pewne doświadczenia o charakterze straty, może odkrywać ich sens lub nawet stwierdzić, iż były one początkiem pewnych zmian biograficznych, tożsamościowych, osobowościowych.

„W przeżywaniu utraty można wskazać na trzy podstawowe komponenty: poznawczy, afektywny i behawioralny" (Steuden, Janowski, 2009, s. 8). Pierwszy z nich dotyczy sposobu wartościowania utraconego dobra, zdobywania i przetwarzania informacji o powodach i okolicznościach straty. Element afektywny jest związany z emocjami towarzyszącymi doświadczaniu straty, behawioralny zaś dotyczy sposobu manifestowania owych emocji w zachowaniu (ibidem). Cierpiący człowiek potrzebuje czasu, aby poradzić sobie ze stratą. Człowiek, który utracił bliską osobę, ma prawo do żałoby. Człowiek, u którego zdiagnozowano przewlekłą chorobę somatyczną ma prawo do płaczu i głośnego wypowiadania swych obaw. Człowiek opiekujący się chorym członkiem rodziny ma prawo do lęku i chwili zwątpienia. Wreszcie, człowiek umierający ma prawo do spokoju i ciszy umożliwiających refleksję. Wydaje się, że zaistnienie każdego z wymienionych komponentów przeżywania straty jest niezbędne do zaakceptowania zaistniałych okoliczności oraz wypracowania własnych mechanizmów radzenia sobie. 
Uświadomienie sobie tego jest ważne przede wszystkim dla osób, które towarzyszą cierpiącemu. Wsparcie otrzymywane ze strony innych osób jest niezwykle ważne, ale aby spełniło swą funkcję powinno być adekwatne do potrzeb i sytuacji cierpiącego. Istotne jest danie cierpiącemu możliwości okazywania swych emocji, wyrażenia swojego żalu, lęku, obawy o przyszłość. Dojrzałe towarzyszenie w cierpieniu staje się ogromnym wyzwaniem, na które nie zawsze przygotowany jest człowiek. Towarzyszenie oznaczać tu będzie stwarzanie przestrzeni do wyrażania prawdziwych emocji, stwarzanie atmosfery sprzyjającej byciu autentycznym. W takich okolicznościach możliwa jest bowiem egzystencjalna refleksja i dialog oparty na zaufaniu.

Psychologowie dostrzegają pewne patologie w ,sposobie doświadczania utraty [...] zarówno wówczas, gdy sposób jej przeżywania jest rażąco nieadekwatny do obiektywnej wartości utraconych zasobów, na przykład brak przeżywania cierpienia w sytuacji utraty ważnych zasobów (śmierć rodzica, sytuacja rozwodu) lub też ujawnianie reakcji emocjonalnych nadmiernie nasilonych bądź przedłużonych w czasie. [...] Przykładem patologii w doświadczaniu utraty może być odroczenie przeżywania żałoby, uporczywe niegodzenie się na utratę partnera w sytuacji rozwodu" (Steuden, Janowski, 2009, s. 8).

$\mathrm{W}$ radzeniu sobie z cierpieniem pomocne jest zarówno wsparcie otrzymywane od innych osób, ale również wiedza wynikająca z poprzednich doświadczeń, będąca efektem uczenia się człowieka.

\section{Edukacyjny wymiar cierpienia}

Teoretycznych założeń do analizy edukacyjnego potencjału cierpienia dostarcza koncepcja Gerharda Riemanna i Fritza Schützego (1992). U jej podstaw leży przekonanie, że w biografii człowieka można odnaleźć okresy charakteryzujące się ładem, spokojem, harmonią, a zachodzące wydarzenia są bądź efektem intencjonalnej aktywności doświadczającego i działającego podmiotu, bądź dzieją się poza stworzonym planem, ale jednostka potrafi wywierać na nie wpływ. Obok nich występują „trajektorie”, a więc okresy naznaczone chaosem, dezintegracją, utratą kontroli, niepokojem, wywołujące długotrwałe konsekwencje emocjonalne, zmiany tożsamości i osobowości, wyznaczające nowe kierunki przebiegu biografii (zob. Prawda, 1989; Riemann, Schütze, 1992; Schütze, 1997; Rokuszewska-Pawełek, 1996; Gajek, 2011; Mazurek, 2011; Mazurek, 2013). Trajektoria w rozumieniu autorów koncepcji oznacza „procesy społeczne, które są ustrukturowane przez łańcuch powiązanych ze sobą zdarzeń, których nie sposób uniknąć bez poniesienia wysokich kosztów, ciągłych załamań, oczekiwań i rosnącego, irytującego poczucia utraty kontroli nad swym położeniem życiowym. Czuje się wtedy, że jest się popychanym, że można jedynie reagować na sity zewnętrzne, których działania się już nie rozumie" (Riemann, Schütze, 1992, s. 92). 
Proces trajektorii wiąże się z doświadczaniem trudnego do opanowania cierpienia (Schütze, 1997, s. 21).

G. Riemann i F. Schütze opracowali scenariusz przebiegu trajektorii. Zdaniem autorów zaistnienie okoliczności pozostających poza intencją i możliwością kontroli człowieka zawsze poprzedzone jest pewnymi symptomami, które zazwyczaj są niezauważane, ignorowane bądź bagatelizowane. Po pewnym czasie okoliczności zewnętrzne zaczynają coraz mocniej ingerować w funkcjonowanie jednostki, co w efekcie uświadamia jej brak możliwości wpływu na przebieg wydarzeń. Na tym etapie dominują negatywne emocje, które wyzwalają poczucie bezradności, hamując (a nawet zupełnie niwelując) aktywność. Szok i dezorientacja powoli ustępują, co umożliwia podjęcie próby rozwinięcia „nowej, chwiejnej równowagi życia codziennego" (Riemann, Schütze, 1992, s. 104). Podejmowane jednak działania zazwyczaj są nieadekwatne, bezskuteczne, a to dodatkowo potęguje siłę trajektorii. Osiągnięcie spokoju na tym etapie jest zatem jeszcze niemożliwe. W efekcie człowiek cierpiący pejoratywnie ocenia jakość życia, a niekiedy tworzy negatywny obraz własnej osoby. Konsekwencją jest całkowite załamanie się ładu codziennych czynności i kryzys tożsamości. Pojawiają się wątpliwości odnośnie do możliwości odzyskania dotychczasowego, uporządkowanego życia. Niebezpieczeństwem jest utrata wiary we własne możliwości i przekonanie o własnej niemocy.

Egzystencja w totalnym chaosie nie jest jednak możliwa, dlatego też pojawiają się ,próby racjonalizacji trajektorii i pogodzenia się z nią” (ibidem, s. 105), które wyzwalają potrzebę oceny nowego położenia życiowego. Dopiero zdefiniowanie zaistniałych okoliczności, podjęcie próby odnalezienia przyczyn cierpienia oraz uporanie się z pytaniem: „dlaczego to właśnie mnie doświadczył taki los?”, rozpoczyna pracę nad trajektorią, która może zakończyć się odzyskaniem nad nią kontroli bądź ucieczką od trajektorii. Ustosunkowanie się do własnego cierpienia, podjęcie wysiłku zmierzającego do odzyskania kontroli nad biegiem wydarzeń umożliwia transgresję człowieka, jest sprawdzianem jego dojrzałości, może inicjować zmiany tożsamości i osobowości.

W myśl przywołanej koncepcji człowiek w obliczu cierpienia nie musi biernie poddawać się wpływowi sytuacji, ale może podjąć wysiłek ukierunkowany na opanowanie „bezładnych procesów” (ibidem, s. 92) dezintegrujących uporządkowaną biografię. „Osoba jako podmiot własnych cierpień i psychofizycznych ograniczeń może nadawać im nowe znaczenie i wartość, a nawet doświadczać zmian rozwojowych ubogacających jej osobowość o cechy altruizmu, empatii, poczucia wspólnoty w trudzie istnienia. Może podjąć świadomą decyzję przetwarzania swego psychofizycznego cierpienia, integrując je ze sferą duchową i w ten sposób nadać cierpieniu nowy sens i wartość" (Okła, 2009, s. 13-14). Postępowanie człowieka cierpiącego uzależnione jest od subiektywnego interpretowania sytuacji życiowej, oceny własnych możliwości poradzenia sobie w zaistniałych okolicznościach oraz otrzymywanego wsparcia ze strony innych osób. Z pewnością pomocna jest mu również 
nadzieja, która w ujęciu Józefa Kozieleckiego odgrywa kluczową rolę w radzeniu sobie z cierpieniem. Nadzieja „otwiera przed człowiekiem przyszłość, ułatwia formułowanie odległych celów, zwiększa wiarę w zdobycie nowych wartości. Ponadto pobudza do działania, pozwala pokonać zakłócenia czynności i spotkane przeszkody, pozwala dokonywać korekty błędów. Bez niej potrzeba samorealizacji straciłaby swoje znaczenie" (Kozielecki, 2006, s. 36).

Kiedy w biografii człowieka dorosłego pojawia się trajektoria, jest on zdolny do wykorzystania zasobów, które w nim tkwią i podjęcia trudu odzyskania kontroli nad biegiem życia. Praca nad trajektorią zazwyczaj jest związana z uczeniem się dorosłego. Na czym polega owo uczenie się? Jest ono związane z refleksją, namysłem człowieka nad własna biografia i minionymi doświadczeniami. Chodzi tu zatem o uczenie się z doświadczeń własnych i innych, uczenie się z biografii, uczenie się w sytuacjach, w codzienności, w podejmowanym działaniu. Tak rozumiane uczenie się przebiega często nieintencjonalnie, nieświadomie, poza instytucjonalnym systemem kształcenia. Jego warunkiem jest jednak refleksyjność i aktywność podmiotu. Celem tak pojmowanego uczenia się jest „,zmierzanie ku pełni człowieczeństwa, ku życiu szczęśliwszemu” (Dubas, 2007, s. 58), ku zrozumieniu tajemnicy życia oraz roli człowieka w nadawaniu mu sensu. Uczący się dorosły zyskuje swoistą mądrość pomagająca odkrywać i rozumieć istotę człowieczeństwa oraz stawać się dojrzałym i refleksyjnym człowiekiem. Z kolei zdobywana wiedza staje się swoistą mądrością życiową, zapisaną w pamięci autobiograficznej, stanowiącą (czasem długo niewykorzystywany) zasób, z którego czerpie się podczas radzenia sobie $\mathrm{z}$ innymi sytuacjami naznaczonymi cierpieniem, wymagającymi konstruktywnego ustosunkowania się. W biografii człowieka zdarzają się jednak i takie momenty, w których wyeliminowanie cierpienia jest niemożliwe. Zadaniem staje się jego akceptacja, nadanie mu znaczenia, zdefiniowanie sensu, a w efekcie godne życie w cierpieniu, adaptacja. Wypracowanie takiego podejścia względem cierpienia jest zadaniem trudnym, a jego wyznacznikiem często staje się rozwój duchowy osoby.

Wśród wielu biografii ludzi doznających przejmującego trudu egzystencji można odnaleźć takie, które potwierdzają możliwość dostrzeżenia i wykorzystania potencjału edukacyjnego i rozwojowego, jaki tkwi w cierpieniu. Na kartach historii okresu II wojny światowej zapisały się biografie tych osób, które pomimo własnego nieszczęścia i lęku o życie troszczyły się o zdrowie i przetrwanie innych, nierzadko skazując siebie na śmierć. Osoby te miały jednak poczucie bycia spełnionym i w podejmowanych ryzykownych działaniach odnajdywały sens swojej egzystencji. Kolejnym przykładem bohaterskiej postawy człowieka cierpiącego jest francuski dziennikarz Jean-Dominique Bauby, który cierpiąc na tzw. syndrom zamknięcia i będąc sparaliżowanym, stworzył książkę „Skafander i motyl”. Jej treść została ,wymrugana” lewym okiem autora. Innych, wręcz heroicznych dokonań ludzi chorych, niepełnosprawnych, samotnych, wykluczonych, ubogich, a więc cierpiących, można przywołać wiele. Wszystkie pokazują, iż w człowieku 
drzemią siły, których istnienia sam wcześniej nie był świadom. Nie można jednak oczekiwać, że każdy człowiek cierpiący podejmie trud uczenia się i rozwoju pod wpływem krytycznych doświadczeń. Czasem sama sytuacja cierpienia jest na tyle trudna, że uniemożliwia podjęcie działania. Czasem z kolei sam podmiot doświadczający trudu nie dostrzega potencjału sytuacji, w której się znalazł bądź dostrzega go, ale nie chce bądź nie może go wykorzystać. Nie zawsze bowiem człowiek dorosły jest przygotowany do tego, aby ujrzeć cierpienie jako szansę na uczenie się osobowe, głębokie, zmieniające struktury poznawcze, przekształcające dotychczasowe schematy myślenia i działania.

\section{Refleksja zamykająca}

Cierpienie stanowi nieodłączny element ludzkiej egzystencji. Jest doświadczeniem nieuchronnym, nieuniknionym, które dotyka każdego człowieka w różnych okresach jego rozwoju. Zwykle sytuacja wywołująca cierpienie zaskakuje, budzi protest, lęk, ale jednocześnie często pobudza do refleksji, otwiera na nowe, odwraca uwagę od tego, co ulotne i doczesne. Człowiek dorosły, którego uporządkowany bieg biografii zostaje zakłócony trajektorią cierpienia, może potraktować nowe okoliczności jako zadanie, kryzys o charakterze rozwojowym i podjąć działanie. Zapoczątkowana $\mathrm{w}$ ten sposób praca nad trajektorią może prowadzić do uczenia się zachodzącego często w codzienności. W tej perspektywie cierpienie staje się czynnikiem wyzwalającym akt transcendencji człowieka.

Nie można jednak oczekiwać, że każdy człowiek odnajdzie w cierpieniu jego potencjał edukacyjny i rozwojowy. Dostrzeżenie i wykorzystanie tegoż potencjału uzależnione jest od wielu czynników, związanych zarówno z samą sytuacją cierpienia, jak i doświadczającym podmiotem. Cierpienie może bowiem prowokować do stawiania pytań i poszukiwania na nie odpowiedzi, może inspirować do działania, zachęcać do zmiany biograficznej, tożsamościowej i osobowościowej. Z drugiej jednak strony może utrudniać bądź nawet blokować jakąkolwiek aktywność, unicestwiać twórczość i samorealizację. Człowiek cierpiący może potraktować sytuację cierpienia jako zadanie rozwojowe i rozpocząć działania, na które dotychczas się nie zdobył. Może jednak zachować się zgoła odmiennie i wycofać się z aktywności edukacyjnej, twórczej, stwarzającej szansę na rozwój i samorealizację. Czasem nawet przeżywane cierpienie może traktować jako swoiste usprawiedliwienie dla własnej bierności. Człowiek dorosły zwykle nie jest odpowiednio przygotowany do tego, aby cierpienie postrzegać jako szansę na transgresję. Przebieg jego dotychczasowej biografii, ale także perspektywiczne myślenie o własnej biografii, formułowane cele na przyszłość będą wysoce implikowały ustosunkowanie się do cierpienia i potraktowanie go jako szansy bądź przeszkody.

Problem edukacyjnego potencjału cierpienia jest wielowymiarowy, stąd zaproponowana tu refleksja nad nim z pewnością nie wyczerpała tematu, a jedynie 
zasygnalizowała jego wielowątkowość i wielopłaszczyznowość. Zagadnienie to jawić się powinno jako niezwykle ważne poznawczo dla andragogów towarzyszących człowiekowi dorosłemu w procesie jego rozwoju osobowego, duchowego, społecznego, często uwikłanego w sytuację cierpienia.

\section{Literatura}

Dubas E., 2007, Wokót paradygmatu uniwersalności w edukacji dorostych, [w:] E. Dubas (red.), Uniwersalne problemy andragogiki i gerontologii, Wydawnictwo Uniwersytetu Łódzkiego, Łódź, s. 41-63.

Frankl V. E., 1998, Homo patients, przeł. R. Czernecki, Z. J. Jaroszewski, Instytut Wydawniczy Pax, Warszawa.

Frankl V. E., 2009, Człowiek w poszukiwaniu sensu, przeł. A. Wolnicka, Wydawnictwo Czarna Owca, Warszawa.

Gajek K., 2011, Biograficzna praca nad trajektoria jako sposób zdefiniowania tożsamości, [w:] E. Dubas, W. Świtalski (red.), Biografia i badanie biografii, T. I, Uczenie się z (własnej) biografii, Wydawnictwo Uniwersytetu Łódzkiego, Łódź, s. 43-50.

Jaspers K., 1978, Sytuacje graniczne, [w:] R. Rudziński, Jaspers, przeł. A. Staniewska, M. Skwieciński, Wiedza Powszechna, Warszawa, s. 186-243.

Kozielecki J., 2002, Transgresja i kultura, Wydawnictwo Akademickie „Żak”, Warszawa.

Kozielecki J., 2006, Psychologia nadziei, Wydawnictwo Akademickie „Żak”, Warszawa.

Jan Paweł II, 2002, Moje ulubione modlitwy. Ewangelia cierpienia, wybór L. Sapienza, przeł. ks. M. Dziubiński, Grupa Wydawnicza Bertelsmann Media, Poznań.

Janowski K., 2009, Pomoc psychologiczna dla osób doświadczających różnych form utraty, [w:] S. Steuden, K. Janowski (red.), Psychologiczne konteksty doświadczania straty, Wydawnictwo KUL, Lublin, s. 207-213.

Mazurek E., 2011, Biograficzne uczenie się kobiety doświadczajacej choroby nowotworowej piersi $w$ świetle teorii andragogicznych, [w:] E. Dubas, W. Świtalski (red.), Biografia i badanie biografii, T. I, Uczenie się z (własnej) biografii, Wydawnictwo Uniwersytetu Łódzkiego, Łódź, s. $51-68$.

Mazurek E., 2013, Biografie edukacyjne kobiet dotkniętych rakiem piersi, Oficyna Wydawnicza Politechniki Wrocławskiej, Wrocław.

Okła W., 2009, Człowiek w sytuacji choroby, [w:] S. Steuden, K. Janowski (red.), Psychologiczne konteksty doświadczania straty, Wydawnictwo KUL, Lublin, s. 13-23.

Popielski K., 2008, Psychologia egzystencji: wartości w życiu, Wydawnictwo KUL, Lublin.

Prawda M., 1989, Biograficzne odtwarzanie rzeczywistości (O koncepcji badań biograficznych Fritza Schütze), „Studia Socjologiczne”, nr 4, s. 81-98.

Riemann G., Schütze F., 1992, „, Trajektoria” jako podstawowa koncepcja teoretyczna w analizach cierpienia i bezładnych procesów społecznych, „Kultura i Społeczeństwo”, nr 2, s. 89-109.

Rokuszewska-Pawełek A., 1996, Miejsce biografii w socjologii interpretatywnej. Program socjologii biografistycznej Fritza Schützego, „ASK. Społeczeństwo. Badania. Metody”, nr 1, s. 37-54.

Schütze F., 1997, Trajektorie cierpienia jako przedmiot badań socjologii interpretatywnej, „Studia Socjologiczne", nr 1, s. 11-56.

Steuden S., Janowski K. (red.), 2009, Psychologiczne konteksty doświadczania straty, Wydawnictwo KUL, Lublin.

Suchocka L., 2007, Psychologiczna analiza cierpienia $w$ chorobie przewlekłej, Towarzystwo Naukowe KUL, Lublin. 